\title{
Contemporary Situation of FDI and its Determinants: Bangladesh Scenario
}

\author{
Md. Nazmus Sadekin ${ }^{1 *}$, Md. Moniruzzaman Muzib², Al Amin Al Abbasi ${ }^{3}$ \\ ${ }^{1,2}$ Assistant Professor, Department of Economics, Mawlana Bhashani Science and Technology University, Tangail-1902, BANGLADESH \\ ${ }^{3}$ Lecturer, Department of Economics, Mawlana Bhashani Science and Technology University, Tangail-1902, BANGLADESH \\ *E-mail for correspondence: sadekin1865@gmail.com \\ Cell Phone: +8801776196547
}

Received: Sep 12, 2015;

Accepted: Sep 26, 2015;

Published: Jan 5, 2016

Source of Support: Nil

No Conflict of Interest: Declared

\begin{abstract}
This paper examines the present FDI scenario of Bangladesh since 1971 along with an explanation of its significant trend. The various trend facilities, exemptions provided by the government of Bangladesh are also mentioned in the paper. Moreover, the paper also investigates those factors that are handle and affects current FDI situation using the annual data for 1996-2010. From the analysis, we found that market size, infrastructure facilities, trade openness, export promotion, labor cost and availability of skilled labor are the important factors that contribute most to affect FDI.
\end{abstract}

Keywords: Foreign Direct Investment, Export Promotion, Economic Development, Employment opportunity, Incentive

\section{INTRODUCTION}

Foreign Direct Investment (FDI) is an investment concerning a long-term relationship, reflecting an enduring interest which is run by a resident entity in one economy to other resident or enterprise in another economy. FDI consists of three core parts: Equity capital, Intra-company loans, and Reinvested earnings. Foreign Direct Investment plays a vital role not only for the highincome countries but also for the low-income countries like Bangladesh. FDI is viewed as a major stimulus to economic growth in developing countries (ODI, 1997). In terms of improving the capacity of the host country to respond to the opportunities offered by global economic integration, FDI can play an important role. For instance, in a country like Bangladesh there exist a long run relationship between tourist arrival and foreign exchange earnings (Aktar et. al, 2014). For this reason, FDI involvement in tourism sector will play a very trigger role in the growth of country's foreign reserve earnings.

During Asian financial crisis of 1997 to 1998 it has been observed that in terms of stability, FDI had several advantages over other types of capital flows. FDI represents a long-term commitment to the host country and contributes significantly to gross fixed capital formation in developing countries (Cho, 2004). During the 1990s and more in recent years there has been a positive change in policies with regard to FDI. These policies are directed more towards bilateral trade agreements and providing investment incentives to foreign investors in all
South Asian countries. With their liberalized approach to FDI and constant changes in improving the FDI policy framework, South Asia has become an important destination for investment (Sahoo, 2006).

Empirical studies have shown that the creation of an adequate investment environment facilitates increased trade and investment activities that are crucial for longterm growth (Mian and Alam, 2006). On the basis of this intricate link between FDI and growth, the trade regime of Bangladesh has been intensely liberalized to maintain the streams of investments and finances from abroad (Kabir, 2007).

Inward FDI to the middle-income countries has the evidence as a stimulus to the economic growth; conventionally at the export-oriented manufacturing sector. This study reviews the long-run trend on the time scale of FDI to Bangladesh over the period 1996- 2010 and major factors determining foreign companies' decisions to invest, in associated with economic growth. There are well-established theories explaining why foreign direct investment takes place and what the potential determining factors are. Some prominent theories are: The Market Imperfection Hypothesis (Hymer, 1976), Internalization Theory (Rugman, 1980), and Eclectic Approach (Dunning, 1988). There can be both vertical and horizontal FDI inflows. If the factor prices are not equalized across countries then it is said that vertical FDI take place (Hanson, 2001), Helpman and Krugman, 1985). On the other hand, horizontal FDI happens because of 
trade costs (Markusen, 1984); (Markusen and Venables, 1998). It is observed that higher trade costs and firm's stronger level of economies scale encourage FDI about exports (Barinard, 1997). There are extensive studies that have explained the determinants of FDI. All the determinants of FDI can be grouped in two categories such as economic conditions and host country policies. Reduced government's ineffectiveness along with supporting policy framework makes Bangladesh as an attractive destination for FDI, which has a positive spillover and significant impacts affect over time through dynamic effects on economic growth. In this study, we want to show the current situation and identify the determinants of FDI inflows in Bangladesh.

The remainder of the paper is structured in the following way. Section 2 renders the methodology of the study. A brief history of FDI and the current situation is illustrated in Section 3. Section 4 represents the determinants of FDI. In section 5 , the concluding remarks of the study are given.

\section{Methodology}

This study is based on secondary data. The time period of the study is considered from 1996 to 2010. The relevant secondary data are collected from different sources like, Statistics Department and Research Department of Bangladesh Bank (Central Bank of Bangladesh), Bangladesh Bureau of Statistics (BBS), Board of Investment of Bangladesh, Bangladesh Bank Bulletin, Economic Trend, Bangladesh Economic Review, and World Investment Report 2010 published by UNCTAD.

\section{Historical Trend and CuRRENT Situation of FDI IN BANGLADESH}

After the birth of the sovereign nation in 1971, the new government attempted to establish a socialist state and adopted the Nationalization Order of 1972 to foster economic growth. $86 \%$ of the industrial sector was brought under government control, including key industries such as sugar, jute, and cotton textiles. But the nationalized industries were inefficient and produced a low amount of output. The losses incurred by the nationalized industries and the economy experienced low growth. Consequently, Bangladesh has undergone a series of policy reforms to overcome the loss of State-owned industries and induces a more capitalistic economy by progressively increasing funding allocations to the private sector. Concerning to the lack of financial ability, knowledge, and management within the nascent economy, the government of a new nation could not solely rely on the domestic financial market for economic growth. While other low-income countries experienced a $3.8 \%$ growth of GNP per capita, Bangladesh struggled at $0.4 \%$ per year till 1985 . In the 1980s, foreign direct investment became vital components for the acceleration of the development of the Bangladesh economy and the Parliament approved the Foreign Private Investment Act. However, FDI rose very little owing to the upheld trade restrictions. The Investment Act of 1989 soon followed to establish the Board of Investment (UNCTAD 2000), the primary objective of which is aimed at attracting and facilitating investment from abroad.

Board of Investment (BOI) was established 1989 which endeavored in to portray a brief on Foreign Investment registered from 1977 to 2010 for Joint venture investment and from 1990-2010 for the 100\% foreign investment projects:

Table-1: FDI Registered with Board of Investment (till June/ 2010)

\begin{tabular}{|l|l|l|l|}
\hline $\begin{array}{l}\text { Foreign } \\
\text { Investment }\end{array}$ & $\begin{array}{c}\text { No. of Units } \\
\text { Registered }\end{array}$ & $\begin{array}{c}\text { Investment } \\
\text { (\$ Million) }\end{array}$ & $\begin{array}{c}\text { Employment } \\
\text { Opportunities } \\
\text { (Person) }\end{array}$ \\
\hline $\begin{array}{l}100 \% \text { Foreign } \\
\text { Investment }\end{array}$ & 418 & 7012.768 & 141957 \\
\hline $\begin{array}{l}\text { Joint Venture } \\
\text { Investment }\end{array}$ & 1179 & 10172.47 & 259207 \\
\hline Total & 1597 & 17185.238 & 401164 \\
\hline
\end{tabular}

Source: Investment Implementation and Monitoring Cell (IIMC), Board of Investment, Board of Investment, Prime Minister's Office, Government of the People's Republic of Bangladesh, Dhaka.

In the below pie diagram, we can see that $65 \%$ of the Foreign Direct Investment occurred in Services sector. Chemical industry became second (29\%).

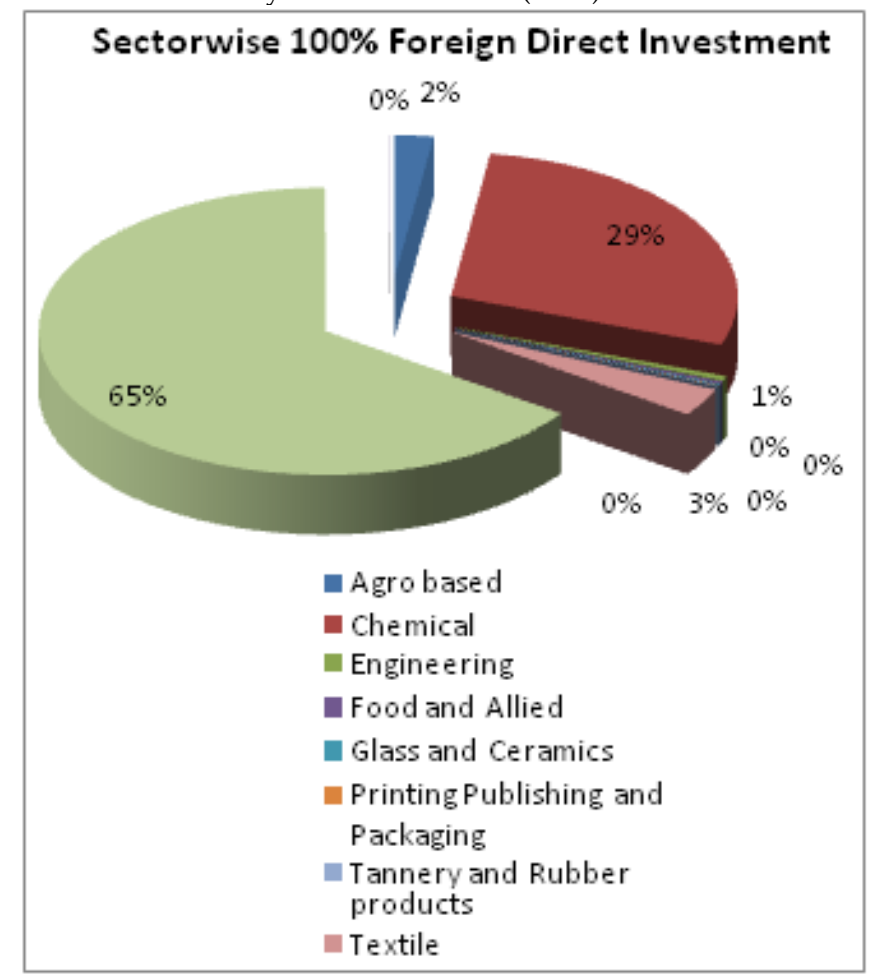

Figure 1: Sector wise Foreign Direct Investment (1996-2010)

In the following table, we can see that from 1996-2010 total \$ 8514.484 Million received as Joint venture investment, that created employment opportunities for 2,49,739 people. From the above 15 years, the best investment occurred in 2008 which was \$2403.328 million. But, the best opportunities created in 2006 of about 40,516 people. 
Table-2: FDI Inflows through Joint Venture Investment (1996-2010)

\begin{tabular}{|c|c|c|}
\hline Year & $\begin{array}{c}\text { Investment } \\
\text { (\$ Million) }\end{array}$ & $\begin{array}{c}\text { Employment } \\
\text { Opportunities (Person) }\end{array}$ \\
\hline 1996 & 616.978 & 6692 \\
\hline 1997 & 1838.911 & 10820 \\
\hline 1998 & 786.09 & 8713 \\
\hline 1999 & 101.657 & 4851 \\
\hline 2000 & 127.779 & 4670 \\
\hline 2001 & 228.445 & 4679 \\
\hline 2002 & 218.827 & 10786 \\
\hline 2003 & 365.974 & 18925 \\
\hline 2004 & 247.894 & 13180 \\
\hline 2005 & 602.498 & 22081 \\
\hline 2006 & 349.148 & 40516 \\
\hline 2007 & 271.687 & 39037 \\
\hline 2008 & 2403.328 & 36677 \\
\hline 2009 & 579.75 & 22590 \\
\hline 2010 & 175.518 & 5522 \\
\hline Total & 8514.484 & 249739 \\
\hline
\end{tabular}

Source: Investment Implementation and Monitoring Cell (IIMC), Board of Investment, Prime Minister's Office, Government of the People's Republic of Bangladesh, Dhaka.

In the below bar diagram, we can see that $66 \%$ of the Foreign Direct Investment occurred in Services sector. Chemical industry became second (14\%). Textile accounted for $11 \%$.

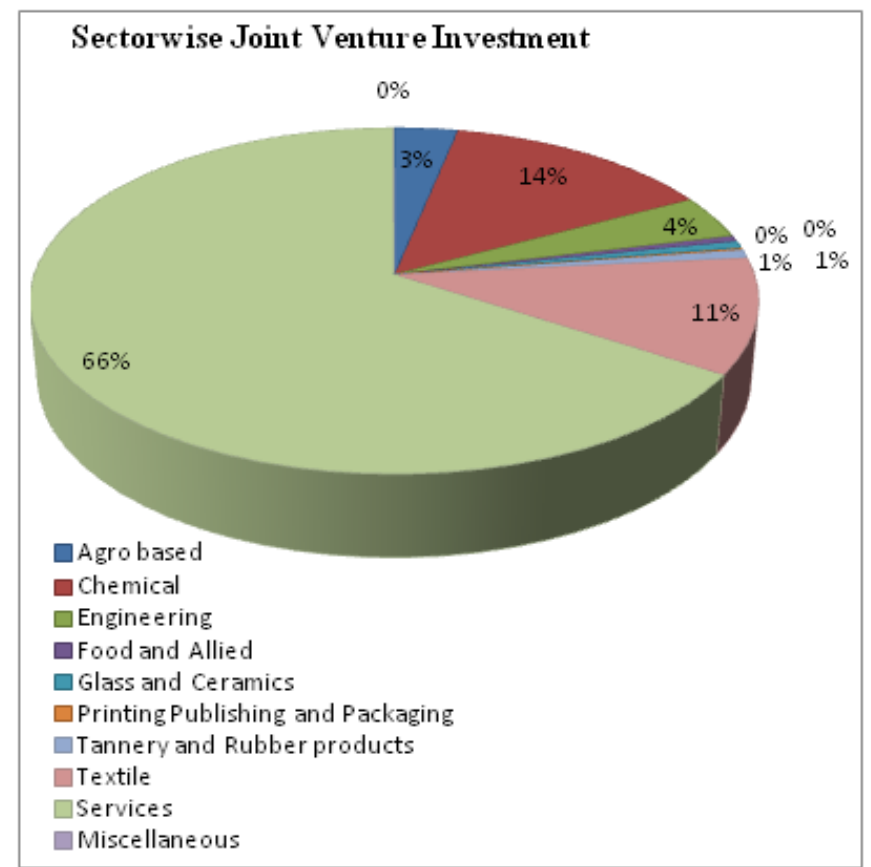

Figure-2: Sector wise Joint Venture Investment (1996-2010)

\section{INCENTIVES TOWARDS FOREIGN DIRECT INVESTMENT}

To encourage the inflows of FDI, Bangladesh offers generous opportunities for investment under its liberalized Industrial Policy and attractive packages of fiscal, financial and other incentives to foreign entrepreneurs. For promoting growth of the country, it provides Major incentives to stimulate private sector direct investment are listed below:

\section{Financial Incentives}

- Cash incentives and export subsidies ranging from 5\% to $20 \%$ granted on the FOB value of the selected products

- $\quad 90 \%$ loans against letters of credit (by banks)

- Permission for domestic market sales of up to $20 \%$ of exportoriented companies outside EPZ (relevant duties apply)

- Funds for export promotion and its credit guarantee scheme

\section{Fiscal incentives}

- 5 to 7 years' tax exemptions are available for many business investments. But, for electric power generation tax exemptions are provided for up to 15 years.

- $\quad$ Reduced corporate tax for 5 to 7 years instead of holding and agricultural depreciation.

- Depreciation on the cost of machinery is admissible for new industrial setting.

- For export-oriented industry, no import duty is applicable. It is about $5 \%$ ad valorem for other industries

- Reduced tariff on import for raw materials capital machinery

\section{Other facilities}

- For the expatriate employees of FDI friendly industries, Exemptions of income tax up to three years.

- Unrestricted exit policy for investors

- $\quad$ Citizenship can be achieved by investing a minimum of US \$500,000 or by transferring US\$1,000,000 to any financial institution.

- $\quad$ Permanent resident ship can be achieved by investing a minimum of US\$75,000

- In remittance, facilities for full repatriation of invested capital, profits and dividends are the norm in most situations

- An investor can repatriate the sales proceeds after securing proper authorization from the Bangladesh Bank.

- Foreign investors with local partners can set up ventures in a joint collaboration.

\section{The Determinants of Foreign Direct InVEStMent}

Economic conditions include market size, growth prospect, the rate of return, urbanization/industrialization, labor cost, human capital, physical infrastructure, and macroeconomic fundamentals like inflation, tax regime, external debt, etc. Host country policies include the promotion of private ownership, efficient financial market, trade policies/free trade policy/regional trade agreements, FDI policies, and perception of country risk, legal framework, and quality of bureaucracy. Empirical research suggests that FDI is sensitive to the host country's overall economic policies, including its tax policy.

\section{Market size}

The aim of FDI in emerging developing countries, like Bangladesh, is to tap the domestic market, and thus market size does matter for domestic market oriented FDI. The market size of Bangladesh is enormous. Thus, an economy with a large market size (along with other 
factors) should attract more FDI. Thus, a large market size provides more opportunities for sales and also profits to foreign firms, and therefore attracts FDI (Wang and Swain, 1995), (Schneider and Frey, 1985).

\section{Labor cost and availability of skilled labor}

Cheap and availability of skilled labor is another important determinant of FDI inflow to Bangladesh. There is a large number of labor in the country whose are always ready to sell their labor with a low wage.

\section{Infrastructure facilities}

When developing countries compete for FDI, the country that is best prepared to address infrastructure bottlenecks will secure a greater amount of FDI. Bangladesh has quality infrastructure, better electricity, water, transportation and telecommunications that are the major determinant of FDI.

\section{Openness and Export Promotion}

Trade openness generally positively influences the export-oriented FDI inflow into an economy. Investors want big markets and like to invest in countries that have regional trade integration, and also in countries where there are greater investment provisions in their trade agreements. Bangladesh fills up such conditions.

\section{CONCLUSION}

This study has gone to show the historical trend and current situations of FDI in Bangladesh. This study also reveals the determinants of FDI of Bangladesh economy. The analysis is performed using annual data for 1996- 2010. The positive industrial and eco-friendly environment attract a foreign investor to invest in this country. The Government of Bangladesh has offered many incentives for foreign investors to attract more foreign direct investment. The argument rests on the fact that foreign investors invariably prefer to invest not only in large markets but also in economies that are experiencing high rates of economic growth. A large inflow of FDI can add to foreign exchange and investment resources in a host economy, but it may deter the development of local firms or create exchange rate problems.

\section{REFERENCES}

Aktar, M. A., Sadekin, M. N., and Saha, S. K. (2014). Relationship between Tourist Arrival and Foreign Exchange Earnings: The Case for Bangladesh. Mediterranean Journal of Social Sciences, 5(16), 162.

Bangladesh Board of Investment (2004). "FDI in Bangladesh during 2004: The 4th FDI Inflow Survey," Dhaka: Board of Investment.

Bangladesh Board of Investment (2010). Foreign Direct Investment in Bangladesh (1971-2010).

Bangladesh Board of Investment, (2002). "Foreign Direct Investment in Bangladesh during 2002: Survey Findings of the First-ever FDI Inflow Survey in Bangladesh", Dhaka: Board of Investment.
Bangladesh Board of Investment, (2003). "FDI in Bangladesh, January-June 2003: FDI Inflow Survey \#2. January-June 2003", Dhaka: Board of Investment.

Brainard, S. L. (1997).An Empirical Assessment ofthe ProximityConcentration Trade-off between Multinational Sales and Trade. American Economic Review 87 (4), 520-44.

Cho, J.W. (2004). Foreign Direct Investment: Determinants, trends in flows and promotion policies in Investment Promotion and Enterprise Development Bulletin for Asia and the Pacific, United Nations, Economic and Social Commission for Asia and the Pacific.

Dunning, J. H. (1988). The Eclectic Paradigm of International Production: A Restatement and Some Possible Extensions. Journal of International Business Studies 19(1), 1-31.

Hanson, G.H. (2001). Should Countries Promote Foreign Direct Investment? G-24 Discussion Paper Series No. 9.

Helpman, E., and Krugman, P. R. (1985), Market Structure and Foreign Trade. Increasing Returns, Imperfect Competition, and the International Economy, Cambridge, MA: MIT Press.

Hymer, S.H. (1976). The International Operations of National Firms: A Study of Foreign Direct Investment. Ph.D. thesis. Massachusetts Institute of Technology, 1960. Cambridge, MA: MIT Press.

Kabir, R. (2007). Foreign direct investment and sustainable growth: A case study on Bangladesh. A thesis submitted to the faculty of Emory College of Emory University. Department of Economics. Retrieved from http://www.docstoc.com/docs/2380675/Foreign-Direct Investment-and-Sustainable-Growth-A-Case-Study-on

Markusen, J. R. (1984). Multinationals, Multi-Plant Economies, and the Gains from Trade. Journal of International Economics, 16 (3-4), 205-26.

Markusen, J. R., and Venables A. J. (1998). Multinational Firms and the New Trade Theory. Journal of International Economics, 46 (2), 183-203.

Mian, M. E. U. and Alam, Q. (2006). Foreign Direct Investment and Development TheBangladesh Scenario. Monash Business Review, 2, 1-3.

ODI (1997). Foreign Direct Investment Flows to Low-Income Countries: A Review of the Evidence. Retrieved from http://www.odi.org.uk/publications/briefing/3_97.html.

Rugman, A.(1980). Internalization as a General Theory of Foreign Direct Investment: A Reappraisal of the Literature. Weltwirtschaftliches Archive, 116(2), 365-379.

Sahoo, P. (2006). "Foreign Direct Investment in South Asia: Policy, Trends, Impact, and Determinants," $A D B$ Institute Discussion Paper NO. 56.

Schneider, F., Frey, B. (1985). Economic and Political Determinants of Foreign Direct Investment. World Development, 13(2), pp. 161-175.

United Nations Conference on Trade and Development (UNCTAD), 2000. “World Investment Report 2005.

Wang, Z, Q. and Swain, N.J. (1995). The Determinants of Foreign Direct Investment in Transforming Economies: Evidence from Hungary and China. Weltwritschaftliches Archive, 131, 359-382.

World Bank Group, Bangladesh Data Profile, The World Bank. Retrieved from http:/ / devddataworldbank.org/external/CPProfile.asp? PTYPE=CP\&CCODE=BGD.

$--0-$ 